\title{
VITAMIN A IN THE BLOOD SERUM, LIVER, CORPORA LUTEA, PLACENTOMAS, AND FETAL FLUIDS OF COWS, AND IN THE BLOOD SERUM AND LIVER OF THEIR FETUSES IN THE LATTER THIRD OF PREGNANCY
}

\author{
Z. VLČEK, J. NEDBÁLKOVÁ, R. SVOBODOVÁ, J. CHLUPÁC̆ \\ Department of Farm Animal Reproduction and Surgery, University of Veterinary Science, \\ 61242 Brno
}

Received May 25, 1979

\begin{abstract}
Vlček Z., J. Nedbálková, R. Svobodová, J. Chlupáč: Vitamin $A$ in the Blood Serum, Liver, Corpora Lutea, Placentomas and Fetal Fluids of Cows, and in the Blood Serum and Liver of Their Fetuses in the Latter Third of Pregnancy. Acta vet. Brno, 49, 1980: $37-44$.

In 74 cows in late pregnancy the concentration of vitamin $A$ in the blood serum, the liver, the corpora lutea, placentomas and the fetal fluids was studied photometrically in the autumn and winter, and compared with the values in the blood serum and liver of the fetuses. The ascertained concentrations of vitamin $A$ in the blood serum of cows moved between the lower limit of physiological range and values of hypovitaminosis. In the period of study they moderately decreased [to the limit of significance $(P<0.10)$ ], whilst reserves deposited in the liver tissue were still high.

The concentration of vitamin $A$ in the blood serum of fetuses $(12.83-18.96$ $\mu \mathrm{g} / 100 \mathrm{ml}$ ) and in the liver tissue of fetuses $(16,41-21,09 \mathrm{UI} / 1 \mathrm{~g})$ were significantly lower $(P<0.01)$ than in the blood serum and liver tissue of cows. The concentrations in the liver of fetuses represented only $3.53-4.39 \%$ amount deposited in the liver tissue of cows in late pregnancy.

The concentrations of vitamin $\mathrm{A}$ in the fetal fluids and placentomas were very low (in the allantoic fluid $10.83-12.72$, in the amniotic fluid $10.11-11.92 \mu \mathrm{g}$ vi$\operatorname{tamin} \mathrm{A} / 100 \mathrm{ml}$, in the placentomas $9.01-16.29 \mathrm{IU}$ in $1 \mathrm{~g}$ tissue) and had a tendency to a moderate decrease in the period studied.

In the corpora lutea high concentrations of vitamin A $(96.12-148.2 \mathrm{IU}$ in $1 \mathrm{~g}$ tissue) which decreased significantly during the studied period and increased significantly with the duration of gravidity, were ascertained.
\end{abstract}

Pregnancy, mother, fetus, vitamin A.

The relation of the metabolic states to reproduction is the subject of intensive research. The ascertainment of the causes, the precision of diagnosis and the discovery of more reliable methods of speedy compensation of metabolic disturbances during gravidity and the puerperium represents further perspectives for the minimizing of losses caused by disturbances of reproduction, a decrease in the utility of cows and disturbances in the health of the young. The work is part of an extensive research program on metabolic disturbances in cattle.

In order to ensure a good level of reproductive functions a very valuable and correspondingly balanced nutrition with relation to proteins, carbohydrates, minerals and vitamins is essential from a biological point of view. Numerous works and empirical information point to the fact that of the biostimulants vitamin $\mathrm{A}$ is most closely related to reproduction and has therefore frequently been referred to as "the vitamin of fertility". At the present time we are acquainted with many pathological changes, which cause disturbances in reproduction when deficient in vitamin $A$. These changes and disturbances in reproduction usually appear prior to a graver damage to the general 
state of health, and thus a good level of reproduction is usually considered to be an indication of a good supply of beta-carotene and vitamin $A$ to the organism.

The saturation of the organism with vitamin A depends upon the level of nutrition and the contents of beta-carotene in the feeds strikingly alters during the year. The daily basic need for a cow is given as approximately $40.000 \mathrm{IU}$ vitamin A (Scheunert and Trautmann 1976; Kudlác 1975 ; Nadai et al., 1970).

According to the method of conservation, the confent of carotene in the feeds decreases to a fourth to tenth of the original amount (Vintan et al. 1970; Hennig et al. 1972) when ruminants make use of a mere $20 \%$ of the accepted feed (Cvetkovič 1966). The lesser choice and worse quality of the feeds causes disturbances in reproduction as a result of qualitatively incorrect feeding, especially in the winter and spring months. A deficiency in beta carotene and the exhaustion of the bodily reserves of vitamin A appeared through the decrease of their level to the lower limit of physiological values, which move between $30-76 \mu \mathrm{g}(90-220 \mathrm{IU})$ in $100 \mathrm{ml}$ blood serum (Slanina 1975). Vintan et al. (1968), registered a decrease from $113.6 \mathrm{IU}$ in January to 19.3 IU vitamin A in $100 \mathrm{ml}$ blood serum in February. In the last weeks of gravidity a physiological decrease takes place in the level of vitamin A and beta-carotene (Jagoš et al. 1978). Recently a specific effect of beta-carotene on the fertility of cattle, independent of vitamin A was evidenced (Lot thammer et al. 1976).

The relation of a deficiency of beta-carotene and vitamin A to disturbances in reproduction in cattle and pre- and postnatal morbidity and mortility of calves has been documented in numerous works (Dvořák 1959, and authors cited by him, Tagwerker 1968; Vlček 1971; Vujovič et al. 1970; Hennig 1972; Mingazov 1976; Lokvančič et al. 1969; Madojan et al. 1970 and others).

According to Moore, Branstetter et al. (1973) the supply of vitamin A to the fetus is markedly smaller than to gravid cows. Harms (1951) ascertained values representing merely $1.5 \%$ the amount of vitamin A in the livers of fetuses, as found in the livers of cows, whereby the reserve deposited in the second half of the intrauterine development was much lower than in the first half. Lambrou (1976) concurrently found much lower levels of vitamin $A$ in the blood serum of precolostral calves than in their mothers. The passage of vitamin A, and still more the passage of beta-carotene through the placental barrier is thus made difficult, but in the case of a large supply of beta-carotene and vitamin A to gravid cows the contents in the blood serum and the livers of the fetuses is enlarged and thus a lower frequency of pathological conditions in the postnatal period is observed (Scheunert and Trautmann 1976 and others).

\section{Materials and Methods}

A study was carried out during the autumn and winter of 1976/1977 and 1977/1987 on 74 late pregnant cows of the Czech spotted cattle, coming chiefly from a farm of the SPZ Nový Jičín. The cows were blood - sampled from the jugular vein. After laparohysterectomy samples of allan-

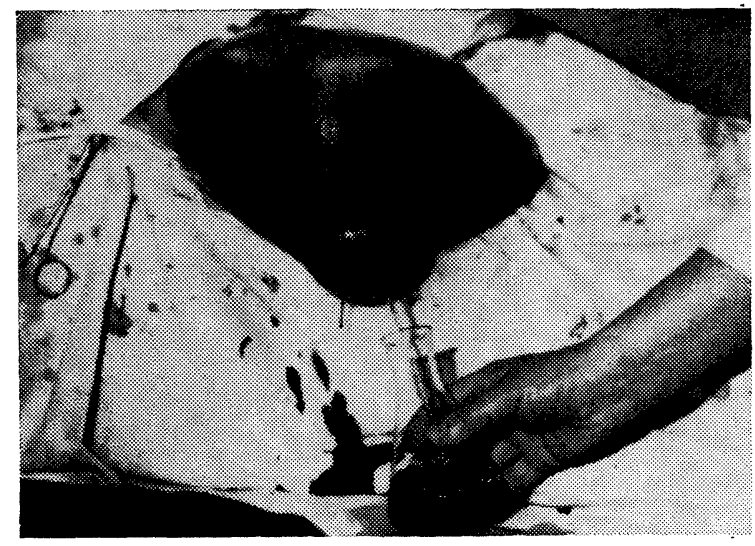

Fig. 1.

Allantoic fluid sampling. 
toic and amniotic fluids were collected (Fig. 1) and in a part of the cases before exsanguination of the fetus, placentomas (Fig. 2). In other cases the placentomas were ligated and collected at the same time as the samples of liver tissue and ovaries (Fig. 3) after the cows were slaughtered. We collected fetal blood from the a. carotis (Fig. 4) of fetuses.

We established the concentration of vitamin A after extraction into petrol-ether, spectrophotometrically in the visible region at $620 \mathrm{~nm}$ by the Carr-Price method, in the placentomas, the corpora lutea and the liver, after extraction into $n$-hexane spectrophotometrically in the UV region at $328 \mathrm{~nm}$ (Knobloch 1956).

The statistical evaluation was carried out by the Student's test.

\section{Results and Discussion}

The concentrations of vitamin A found in the blood serum of cows in late pregnancy was predominantly at the lower limit of the physiological range, and in some of the cows concentrations were ascertained, which are looked

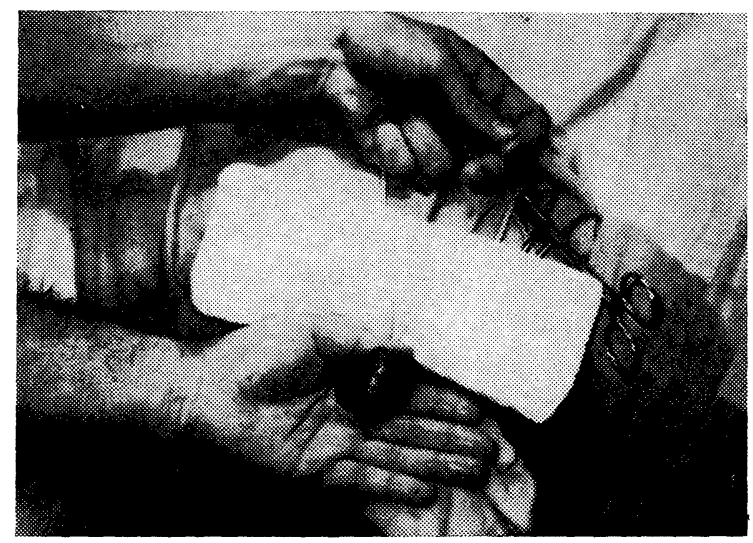

Fig. 2.

Ligature of a placentoma before bleeding of the fetus.

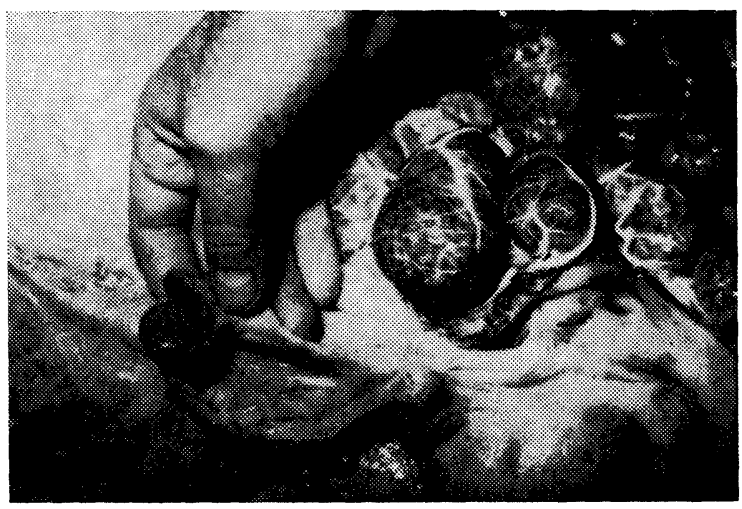

Fig. 3.

Sampling of the corpus luteum. 


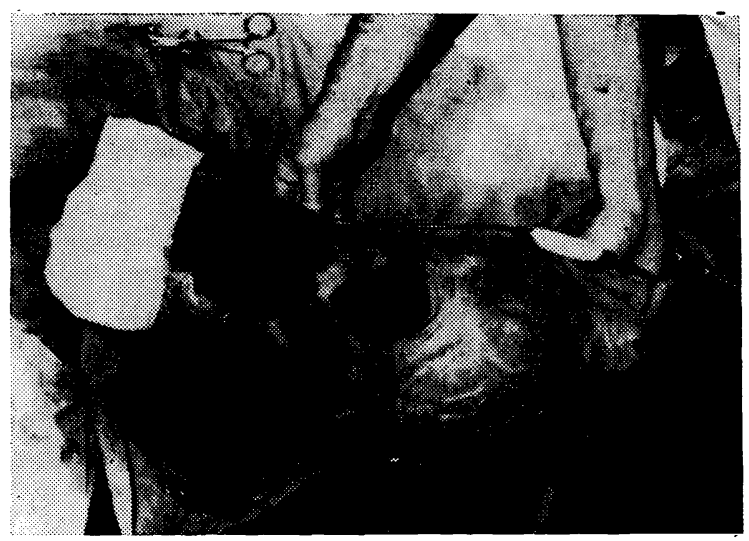

Fig. 4.

Blood sampling from the a. carotis of the fetus.

upon as close to hypovitaminosis (Hennig et al. 1972; Slanina 1975). If we compare the results in cows operated in September/October with values ascertained in November/December and January/February (Table 1), a tendency to a moderate decrease in the mean concentration of vitamin A from $55.55 \mu \mathrm{g}$ to $48.26 \mu \mathrm{g}$ and $46.81 \mu \mathrm{g} / 100 \mathrm{ml}$ blood serum can be seen. Differences between concentrations in September/October and January/February, are, however, at the limit of statistic significance $(P<0.10)$. The ascertained mean concentration of vitamin A in the livers of cows (485.10 IU in September/October, $472.88 \mathrm{IU}$ in November/December and 493,91 IU in $1 \mathrm{~g}$ tissue in January/February) evidence that the deposited reserves were rather high during the period of study. Unfortunately, technical reasons prevented us from carrying out the

Table 1

Contents of vitamin $A$ in the blood serum, liver, corpora lutea, placentomas, fetal fluids of cows, and in the blood serum and liver of fetuses in relation to the season

\begin{tabular}{|c|c|c|c|}
\hline & September/October & November/December & January/February \\
\hline $\begin{array}{l}\text { Blood serum } \\
\text { cow }-\mu \mathrm{g} / 100 \mathrm{ml}\end{array}$ & $55,55 \pm 15,09$ & $48,26 \pm 13,63$ & $46,81 \pm 13,78$ \\
\hline Liver cow IU/1 g & $485,10 \pm 252,42$ & $472,88 \pm 249,36$ & $493,91 \pm 293,00$ \\
\hline $\begin{array}{l}\text { Corpora lutea } \\
\text { cow - IU /1 g }\end{array}$ & $165,23 \pm 49,87$ & $116,34 \pm 53,70$ & $107,15 \pm 56,71$ \\
\hline Placentoma cow IU/1 g & $15,11 \pm 12,51$ & $18,55 \pm 17,44$ & $9,05 \pm 4,16$ \\
\hline $\begin{array}{l}\text { Allantoic fluid } \\
\text { cow }-\mu \mathrm{g} / 100 \mathrm{ml}\end{array}$ & $13,58 \pm 7,61$ & $12,96 \pm 3,77$ & $10,67 \pm 4,85$ \\
\hline $\begin{array}{l}\text { Amniotic fluid } \\
\text { cow }-\mu \mathrm{g} / 100 \mathrm{ml}\end{array}$ & $14,69 \pm 6,11$ & $10,13 \pm 3,66$ & $10,74 \pm 4,99$ \\
\hline $\begin{array}{l}\text { Blood serum } \\
\text { fetus }-\mu \mathrm{g} / 100 \mathrm{ml}\end{array}$ & $19,89 \pm 10,85$ & $19,63 \pm 6,13$ & $14,24 \pm 7,73$ \\
\hline Liver fetus IU/1 g & $16,13 \pm 11,07$ & $30,80+15,82$ & $14,86 \pm 6,51$ \\
\hline
\end{tabular}


study for more months, in which case there would probably have been a more expressive decrease in the values of vitamin $A$ after the exhaustion of the bodily reserves. Conclusive deviations show a marked imbalance in the values, which could have been caused by the varied level of nutrition or the ability conversion of vitamin A.

In concurrence with Branstetter et al. (1973), Baetz and Hubert (1974), Jagoš et al. (1978), and Lambrou (1976), we demonstrated a more markedly decrease concentration of vitamin $A$ in the blood serum of fetuses (12.83 to $18.96 \mu \mathrm{g} / 100 \mathrm{ml}$ ) than in the blood serum of late pregnant cows. The differences are statistically very significant $(P<0.01)$. The concentrations of vitamin A in the blood serum of fetuses also indicated a moderate decrease from $19.89 \mu \mathrm{g}$ in September/October to $19.63 \mu \mathrm{g}$ in November/December and a significant decrease $(P<0.05)$ to $14.24 \mu \mathrm{g} / 100 \mathrm{ml}$ blood serum in January/February. Similar values were ascertained by Surynek et al. (1976) in the blood serum of calves aged $0-7$ days $(\varnothing 16.7 \mu \mathrm{g} / 100 \mathrm{ml})$, whilst in calves aged 8-14 days the mean values increased to $29.8 \mu \mathrm{g}$ vitamin $\mathrm{A} / 100 \mathrm{ml}$ blood plasma.

We found still greater significant $(P<0.01)$ differences in the supply of vitamin A amongst cows in late pregnancy and their fetuses in all the groups, when evaluating the amount of vitamin A deposits in the liver. Whilst marked reserves were deposited in the livers of cows (see above-mentioned mean values), we ascertained only 16.13 IU vitamin A in the fetal liver tissue in September/October, in November/December $30.80 \mathrm{IU}$, and in January/February 14.86 IU.

In order to ascertain the relation of the duration of gravidity to the supply of vitamin A to the mother and the fetus, we placed gravid cows in 4 groups with a duration of gravidity of 249 days, $250-259$ days, 260-269 days and 270 and more days (Table 2 and 3 ). However, we were unable to ascertain any significant differences in the concentration of vitamin $A$ in the blood serum and the liver in the cows in this short space of time. Similarly the content of vitamin A in the

Table 2

Contents of vitamin $A$ in the blood serum and liver of cows and their fetuses in relation to the duration of pregnancy

\begin{tabular}{|c|c|c|c|c|c|}
\hline \multirow{2}{*}{$\begin{array}{c}\text { Duration of pregnancy } \\
\text { (days) }\end{array}$} & \multirow[b]{2}{*}{ No. cases } & \multicolumn{2}{|c|}{ Blood serum } & \multicolumn{2}{|c|}{ Liver } \\
\hline & & $\stackrel{\text { cow }}{\mu \mathrm{g} / 100 \mathrm{ml}}$ & $\begin{array}{l}\text { fetus } \\
\mu \mathrm{g} / 100 \mathrm{ml}\end{array}$ & $\begin{array}{c}\text { cow } \\
\text { IU } / 1 \mathrm{~g}\end{array}$ & $\begin{array}{l}\text { fetus } \\
\text { IU } / 1 \mathrm{~g}\end{array}$ \\
\hline $\begin{array}{c}\text { to } 249 \\
250-259 \\
260-269 \\
270 \text { and more }\end{array}$ & $\begin{array}{l}20 \\
16 \\
22 \\
16\end{array}$ & $\begin{array}{l}43,62 \pm 13,49 \\
45,24 \pm 11,39 \\
43,20 \pm 15,57 \\
41,70 \pm 15,26\end{array}$ & $\begin{array}{l}18,96 \pm 6,97 \\
16,37 \pm 5,98 \\
12,83 \pm 6,37 \\
18,74 \pm 12,12\end{array}$ & $\begin{array}{l}476,54 \pm 228,88 \\
496,13 \pm 239,86 \\
463,67 \pm 174,00 \\
532,77 \pm 384,39\end{array}$ & $\begin{array}{l}20,70 \pm 15,55 \\
20,26 \pm 8,56 \\
16,41 \pm 7,59 \\
21,09 \pm 12,93\end{array}$ \\
\hline
\end{tabular}

Table 3

Contents of vitamin $A$ in placentomas, corpora lutea, allantoic and amniotic fluids of cows in relation to the duration of pregnancy

\begin{tabular}{|c|c|c|c|c|c|}
\hline $\begin{array}{c}\text { Duration of pregnancy } \\
\text { (days) }\end{array}$ & $\begin{array}{c}\text { No. of } \\
\text { cases }\end{array}$ & $\begin{array}{c}\text { Placentoma } \\
\text { IU/1 g }\end{array}$ & $\begin{array}{c}\text { Corpora lutea } \\
\text { IU } / 1 \text { g }\end{array}$ & $\begin{array}{c}\text { Allantoic fluid } \\
\mu \mathrm{g} / 100 \mathrm{ml}\end{array}$ & $\begin{array}{c}\text { Amniotic fluid } \\
\mu \mathrm{g} / 100 \mathrm{ml}\end{array}$ \\
\hline & 20 & $14,21 \pm 12,44$ & $96,12 \pm 44,79$ & $11,42 \pm 5,68$ & $11,57 \pm 3,93$ \\
to 249 & 16 & $16,29 \pm 11,90$ & $132,98 \pm 64,82$ & $11,92 \pm 3,44$ & $10,11 \pm 3,55$ \\
$250-259$ & 22 & $9,27 \pm 4,05$ & $123,43 \pm 56,57$ & $12,72 \pm 6,57$ & $11,92 \pm 7,34$ \\
$260-269$ & 16 & $9,01 \pm 6,50$ & $148,20 \pm 55,09$ & $10,83 \pm 5,32$ & $10,78 \pm 5,81$ \\
\hline
\end{tabular}


liver tissue of the fetuses did not significantly alter in this period, whilst its concentration in the blood serum significantly decreased in fetuses aged 260-269 days $(P<0.05)$ as compared with the values in fetuses aged 249 days and at the limit of significance $(P<0.10)$ in comparison with fetuses aged 250-259 days and 270 and more days.

The concentrations of vitamin $A$ in the fetal fluids were very low - we ascertained a mean concentration of $10.83-12.72 \mu \mathrm{g}$ vitamin $\mathrm{A} / 100 \mathrm{ml}$ in the allantoic fluid $10.11-11.92 \mu \mathrm{g}$ vitamin $\mathrm{A} / 100 \mathrm{ml}$ in the amniotic fluid in the individual groups of cows with various duration of gravidity. Even this small amount had a tendency to a moderate decrease in the studied period - in the allantoic fluid from $13.58 \mu \mathrm{g}$ in September/October to $12.96 \mu \mathrm{g}$ in November/December, and $10.67 \mu \mathrm{g}$ vitamin $\mathrm{A} / 100 \mathrm{ml}$ fluid in January February, in the amniotic fluid from $14.69 \mu \mathrm{g}$ in September/October to $10.13 \mu \mathrm{g}$ in November/December and $10.74 \mu \mathrm{g}$ vitamin $\mathrm{A} / 100 \mathrm{ml}$ in January/February.

The amount of vitamin $\mathrm{A}$ in the placentomas was also very small, and in the months of September/October and November/December somewhat larger (15.11 IU and 18.55 IU in $1 \mathrm{~g}$ tissue) than in January/February (9.05 IU in $1 \mathrm{~g}$ tissue). The differences are at the limit of significance $(P<0.10)$. In cows with a duration of gravidity up to 249 days and $250-259$ days, the amount of vitamin $\mathrm{A}$ in the placentomas was somewhat larger (14.21 and $16.29 \mathrm{IU}$ in $1 \mathrm{~g}$ tissue) than in cows pregnant from 260 to 269 days and 270 and more days (9.27 and $9.01 \mathrm{IU}$ in $1 \mathrm{~g}$ of tissue). In cows with a duration of gravidity of 260-269 days in comparison with the values in cows gravid 250-259 days a decrease was significant $(P<0.05)$, in cows with a duration of gravidity of 270 and more days it was at the limit of significance $(P<0.10)$.

The corpora lutea were relatively rich in vitamin $A$. In these the ascertained mean values increased with the duration of gravidity - from 96.12 IU in $1 \mathrm{~g}$ tissue in cows pregnant for 249 days to 132.98 IU in cows gravid 250-259 days, 123.43 IU in cows gravid 260-269 days and 148.20 IU in $1 \mathrm{~g}$ tissue, in cows gravid 270 and more days. The difference in values ascertained in cows pregnant for 249 days and 270 and more days is statistically significant $(P<0.05)$.

Mean values of vitamin A ascertained in the corpora lutea decreased in the course of the studied season from 165.23 IU in $1 \mathrm{~g}$ tissue in September/October to $116.34 \mathrm{IU}$ in November/December and $107.15 \mathrm{IU}$ in $1 \mathrm{~g}$ tissue in January/ /February. The difference between the values in September/October and January/February is significant $(P<0.01)$. The ascertained high concentration of vitamin $\mathrm{A}$ in the corpora lutea indicates its probable significance for the synthesis of progesterone, as was proved for glucocorticosteroids and other steroids, mucopolysaccharides, and for other processes required for the undisturbed course of pregnancy (Moore 1970 and others).

Vitamín A v krevním séru, játrech, žlutém tělísku, placentomech, plodových vodách krav a krevním séru a játrech plodư v poslední třetině nitroděložního vývoje

U 74 vysokobřezích krav byla $\mathrm{v}$ podzimním a zimním období sledována spektrofotometricky koncentrace vitamínu A v krevním séru, játrech, žlutém tělísku, placentomech, alantoidové a amniové tekutině a srovnána s hodnotami v krevním séru a játrech fétů. 
Zjištěné koncentrace vitaminu A v krevnim séru krav se pohybovaly mezi dolni hranicí fyziologické normy a hypovitaminózními hodnotami. V sledovaném období došlo $\mathrm{k}$ jejich mírnému snížení (na hranici statistické významnosti : $P<0.10$ ), zatímco rezervy deponované $\mathrm{v}$ jaterní tkáni byly dosud vysoké.

Koncentrace vitamínu A v krevním séru fétu $(12,83-18,96 \mu \mathrm{g} / 100 \mathrm{ml})$ a v jaterní tkáni fétů $(16,41-21,09 \mathrm{~m} . \mathrm{j} . / 1 \mathrm{~g})$ byly statisticky vysoce významně nižší $(P<0,01)$ než v krevním séru a jaterní tkáni krav. Koncentrace $\mathrm{v}$ jaterní tkáni fétů reprezentovaly pouze $3,53-4,34 \%$ množství deponovaného $\mathrm{v}$ jaterní tkáni vysokobřezích krav.

Koncentrace vitamínu A v plodových vodách a placentomech byly velmi nízké (v alantoidové tekutině $10,83-12,72 \mu \mathrm{g}, \mathrm{v}$ amniové tekutině $10,11-11,92 \mu \mathrm{g}$ vitamínu $\mathrm{A} / 100 \mathrm{ml}$, v placentomech $9,01-16,29 \mathrm{~m}$. j. v $1 \mathrm{~g}$ tkáně) a v sledovaném ročním období měly tendenci $\mathrm{k}$ mírnému poklesu.

Ve žlutých tělískách byly zjištěny vysoké koncentrace vitamínu A(96,12-148,20 m. j. v $1 \mathrm{~g}$ tkáně), které se statisticky vysoce významně snižovaly během sledovaného ročního období a statisticky významně zvyšovaly s délkou gravidity.

Витамин А в кровяной сыворотке, печени, желтом теле, плацентомах, сколоплодных водах коров и в сыворотке крови и в печени плодов в последней трети внутритрубного развития

У 74 коров с высокой беременностью в осенний и зимний период проводились спектрофотометрические исследования -концентрации витамина 1 в кровяной сыворотке, печени, желтом теле, плацентомах, аллантоидной и амниотической жидкостях и проводились сравнения с величинами в кровяной сыворотке и печени зародышей.

Выявленная концентрация витамина А в кровяной сыворотке коров колебалась между нижним пределом физиологической нормы и гиповитаминозными величинами. В исследуемый период произошло их незначительное понижение (на грани статистической значимости $-\mathrm{P}<0,10$ ), между тем как хранящийся в ткани печени резерв был довольно высоким.

Концентрация витамина А в кровяной сыворотке зародышей $(12,83$ 18,96 тд/100 мл) и в ткани печени зародышей $(16,41-21,09$ е. и /1 г) была статистически существенно значимо ниже $(\mathrm{P}<0,01)$ по сравнению с кровяной сывороткой и тканью печени коров. Концентрация в ткани печени зародышей составляла $3,53-4,34 \%$ количества, хранимого в ткани печени коров высокой беременности.

Концентрация вытамина А в околоплодных водах и плацентомах была весьма низкой (в аллантоидной жидкости 10,83-12,72 тд, в амниотической жицкости 10,11-11,92 тд витамина A/100 м, в плацентомах 9,01-16,29 е. и. на 1 г ткани) и в наблюдаемый период года отличалась тенденцией, ғаправленной на незначительное понижение.

В желтых телах были установлены высокие концентрации витамина А ( С6,12-148,20 е. и. на 1 г ткани), которые статистически существенно значимо понижались в течение исследуемого периода времени и статистически существенно повышались с продолжительностью беременности. 


\section{References}

BAETZ, A. L. - HUBBERT, W. T.: Vitamin A in the Bovine Fetus. Am. J. Vet. Res., 35, 1974: $1189-1190$.

BRANSTETTER, R. F. - TUCKER, R. E. - MITCHELL, G. E. - Jr. BOUNG, J. A. BRADLEY, N. W.: Vitamin A Transfer From Cows to Calves. 43, 1973: 142-146.

CVETKOVIC, A.: Uticaj deficita u vitaminu A na pojavu gastrointestinalnih oboljenja novorodenih teladi. Acta vet. Beograd, 16, 1966: 433-440.

DVOŘÁ, M.: Vitamin A a karoten v krevní plazmě sajících telat a jejich závislost na mateřském organismu. Sbornik VŚZL 7 (28), řada B, 4, 1959: 339-417.

HARMS, F.: Vitamin A in Fetus und Jungtier bei Rind und Pferd. Mh. Vet. Med., 6, 1951: $165-169$.

HENNIG, A. - ANKE, M. - BOCKER, M. - GRUMN, K. - KRAUSE, E. - OETTEL, M. - PRUSAS, E. - WEBER, R. - WERNER, B. - WÜNSCHE, E.: Mineralstoffe-Vitamine-Ergotropika. DDR-VEB Deutsch. Landwirtschaftsverlag, Berlin, 1972, 636 pp.

JAGOŚ, P. - BOUDA, J. - DVORÁK, V. - DVOŘ́K, R. - HAMŠ́́,, V. - VALACH, Z.: Studium aktivity enzymů, hladiny vitaminů a bílkovin $v$ různých fázích ontogeneze $u$ telat při metabolických poruchách. Project report, VŠV Brno, 1978, 84 pp.

KNOBLOCH, E.: Fyzikálně chemické metody stanovení vitaminů. ĊÂV, Praha, 1956, 458 pp.

KUDLÁC, E.: Význam některých stopových prvkủ a vitaminů pro plodnost hospodárských zvírat. Reprodukce a genetika hospodářských zviŕat. ÚVO, Pradubice, 1975, 2, 21-29.

LAMBROU, L.: Obsah některých minerálií, cukrů, enzymů a vitaminu A v krevním séru krav a jejich plodů ke konci březosti a po porodu. Thesis, VŠV Brno, 1976, $81 \mathrm{pp}$.

LOKVANČIČ, H. - PENAVIN, V. - MUTELEV, A.: Primjena vitamina A i $\mathrm{D}_{3}$ kod krava u zadnjem stadiu gravidnosti i rozličitim gogišnjim dobima kao prilog istraživanju uloge vitamina $\mathrm{u}$ etiologii retencije sekundina. Veterinaria Sarajevo, 18, 1969: 511-517.

LOTTHAMMER, K. H. - AHLSWEDE, L. - MEYER, H.: Untersuchungen über eine spezifische Vitamin - A - unabhängige Wirkung des Beta-Carotins auf die Fertilität des Rindes. 2. Mittelung: Weitere klinische Befunde und Befruchtungsergebnisse. Dtsch. tierärztl. Wschr., 83, 1976: 353-358.

MADOJAN, D. - ISACHANJAN, S. S.: Dějvstvije obesftorennogo fosfata i vitamina A na polovuju funkciju korov. Veterinarija, 25, 1970: 90-92.

MINGAZOV, T. A.: Profilaktika embryonal'noj smertnosti krupnogo rogatogo skota trivitaminom. Vest. sel. choz. Nauki Kazachstana, 19, 1976: 79-82.

MOORE, T. in: MORTON, R. A.: Fat Soluble Vitamins. Pergamon Press 1970, 223-265.

MORTON, R. A.: Fat Soluble Vitamins. Internat. Encyclopaedia of Food and Nutrition. Vol. 9, 1970. Pergamon Press, 1970, 530 pp.

NADAI, J. - BRUBACHER, G.: The Use of Fat Soluble Vitamins and Carotenoids in Animal Nutrition. In: MORTON, R. A.: Fat Soluble Vitamins. Pergamon Press, 1970; 449-487.

SCHEUNERT, A. - TRAUTMANN, A.: Lehrbuch der Veterinär-Physiologie. Berlin-Hamburg, Verlag Paul Parey, 1976, 988 pp.

SLANINA, L.: Klinická propedeutika a diagnostika vnútorných chorôb hospodárskych zvierat. Príroda, Bratislava, 1975, 574 pp.

SURYNEK, J. - KUČERA, A. - BRANDEJS, P.: Hladina beta-karoténu a vitamínu A v krvi kojených telat a jejich matek. Vet. Med. 21, 1976: 557-563.

SURYNEK, J. - SLÁMOVÁ-ŠKOLKOVÁ, Z. - JURKA, F.: Hladina beta-karoténu a vitamínu A v krevní plazmě telat $\mathrm{v}$ prvních čtyřech měsících postnatálního údobí. Vet. Med., 21, 1976: 669-674.

TAGWERKER, F. J.: Vitaminversorgung und Fortpflanzunsstörungen des Rindes, Schw. A. f. Tierheilkd., 110, 1968: 372-385.

VINTAN, A. - BIRUESCU, A. - MILOS, M. - GHERDAN, A.: Carotenul si vitamina A in singe lapte si colosten la vasi in timpul iernii. Lucrări stiint. Ser. Med.vet., 10, 1968: 325-338.

VINTAN, A. - BIRUESCU, A. - GHERDAN, A. - MILOS, M. - PALINCAS, A.: Carotenul placentar si afectiunile digestive ale viteilor non-născuti. Rev. Zoot. Med. vet., 20, 1970: $35-44$.

VLČEK, Z.: Vitamin A ve vztahu k reprodukci skotu a prasat. ÚVO, Pardubice, 1971. 2, 48-65.

VUJOVIC, R. - DAVIDOVIČ, A. - ILIC, V. - STARČEVIČ, S.: O uticaju koncentracije $\mathrm{Ca}, \mathrm{P}, \mathrm{Cu}$ i vitamina A u krvi na reprodukciju krava. Veterinaria Sarajevo, 19, 1970: 563-567. 